\title{
EFFECT OF INTEGRATED NUTRIENT MANAGEMENT IN BORO RICE CULTIVATION
}

\author{
B. Roy, M. A. R. Sarkar and S. K. Paul \\ Department of Agronomy, Bangladesh Agricultural University, Mymensingh-2202, Bangladesh
}

\begin{abstract}
An experiment was carried out in the farmer's field of village Boira under Kotoali Thana, District-Mymensingh in Boro season (Jannuary to May 2013) to find out the effect of integrated nutrient management in Boro rice cv. BRRI dhan29 cultivation. The experiment consisted of the following treatments- control (no manure and no fertilizer) $\left(T_{1}\right)$, recommended dose of prilled urea and PKSZn $\left(T_{2}\right), 50 \%$ of the recommended dose of prilled urea and PKSZn + cowdung $5 \mathrm{tha}^{-1}\left(\mathrm{~T}_{3}\right), 50 \%$ of recommended dose of prilled urea and PKSZn + poultry manure $2.5 \mathrm{tha}^{-1}\left(\mathrm{~T}_{4}\right), 50 \%$ of recommended dose of prilled urea and PKSZn + cowdung $10 \mathrm{t} \mathrm{ha}^{-1}\left(\mathrm{~T}_{5}\right)$, $50 \%$ of recommended dose of prilled urea and PKSZn + poultry manure $5 \mathrm{t} \mathrm{ha}^{-1}\left(\mathrm{~T}_{6}\right)$, cowdung $10 \mathrm{tha}^{-1}\left(\mathrm{~T}_{7}\right)$, poultry manure $5 \mathrm{t} \mathrm{ha}^{-1}\left(\mathrm{~T}_{8}\right)$, full dose of USG $(2.7 \mathrm{~g})$ + recommended dose of PKSZn $\left(\mathrm{T}_{9}\right)$, full dose of USG $(2.7 \mathrm{~g})+$ cowdung $10 \mathrm{t} \mathrm{ha}^{-1}\left(\mathrm{~T}_{10}\right)$, full dose of USG $(2.7 \mathrm{~g})$ + poultry manure $5 \mathrm{t} \mathrm{ha}^{-1}\left(\mathrm{~T}_{11}\right)$, full dose of USG $(2.7 \mathrm{~g})+$ cowdung $5 \mathrm{t} \mathrm{ha}^{-1}\left(\mathrm{~T}_{12}\right)$, full dose of USG $(2.7 \mathrm{~g})$ + poultry manure $2.5 \mathrm{t} \mathrm{ha}^{-1}\left(\mathrm{~T}_{13}\right)$, USG $(1.8 \mathrm{~g})+$ poultry manure $5 \mathrm{tha}^{-1}\left(\mathrm{~T}_{14}\right)$, USG $(1.8 \mathrm{~g})+$ poultry manure $2.5 \mathrm{t} \mathrm{ha}^{-1}\left(\mathrm{~T}_{15}\right)$ and farmer's practice (Urea $250 \mathrm{~kg} \mathrm{ha}^{-1}$, TSP $220 \mathrm{~kg} \mathrm{ha}^{-1}$, MoP $130 \mathrm{~kg}$ $\mathrm{ha}^{-1}$, gypsum $\left.130 \mathrm{~kg} \mathrm{ha}^{-1}\right)\left(\mathrm{T}_{16}\right)$. The experiment was laid out in a randomized complete block design with three replications. Results of the experiment showed that integrated nutrient management had significant effect on yield contributing characters and yield of BRRI dhan29. The tallest plant $\left(93.33 \mathrm{~cm}\right.$ ) was found in $T_{2}$ treatment (recommended dose of prilled urea and PKSZn), the highest number of total tillers hill ${ }^{-1}(16.85)$ and effective tillers hill ${ }^{-1}$ (15.90) were obtained in $T_{11}$ treatment (USG $(2.7 \mathrm{~g})+$ poultry manure $\left.5 \mathrm{t} \mathrm{ha}^{-1}\right)$. The highest 1000 -grain weight $(22.40 \mathrm{~g})$, grain yield $\left(7.19 \mathrm{t} \mathrm{ha}^{-1}\right)$ and straw yield $\left(8.08 \mathrm{t} \mathrm{ha}^{-1}\right)$ were recorded in $\mathrm{T}_{10}$ treatment (full dose of USG $(2.7 \mathrm{~g})+$ cowdung $10 \mathrm{t} \mathrm{ha}^{-1}$ ) and the lowest grain yield $\left(4.43 \mathrm{tha}^{-1}\right)$ and straw yield $\left(5.21 \mathrm{t} \mathrm{ha}^{-1}\right)$ were obtained in $\mathrm{T}_{7}$ treatment (cowdung $10 \mathrm{t} \mathrm{ha}^{-1}$ ). From the study, it can be concluded that inorganic fertilizer along with manure greatly influence the
\end{abstract}

\footnotetext{
*Corresponding author email: skpaull@gmail.com
} 
yield contributing characters and yield of Boro rice and full dose of USG (2.7g) with cowdung $\left(10 \mathrm{tha}^{-1}\right)$ appears as the promising combination for Boro rice (cv. BRRI dhan29) cultivation.

Keywords: Integrated nutrient management, boro rice, yield

\section{ITRODUCTION}

Rice (Oryza sativa L.) is the major food crop in Bangladesh. Boro rice covers about $48.97 \%$ of total rice area and contributes to $38.14 \%$ of total rice production in the country (BBS, 2012). Rice production area is decreasing due to high population pressure. Cultivation of improved varieties and proper nutrient management are the most effective means to meet the demand. For maximizing yield, nutrient management is the key element in rice farming. Depletion of soil fertility has been identified as a major constraint for higher crop yield. The role of fertilizers and manures in increasing the productivity of crop is well known. Repeated use of inorganic fertilizer alone fails to sustain desired yield, impairs the physical condition and reduce the organic matter content of soils (Rabindra et al., 1985; Bhatia and Shukla, 1982; Lal and Mathur, 1988). Integrated use of organic and inorganic fertilizer has been found to be promising for sustainable crop production. This has been amply proved by the long term fertilizer experiments (Nambiar and Abrol, 1989). This indicates that an integrated use of organic and inorganic fertilizers proposed to be an effective approach for sustainable crop production, which is agreed with the opinion of Rabindra et al. (1985), and Bhatia and Shukla (1982).

Nitrogen is the key nutrient required in the largest quantities while urea is the principal nitrogenous fertilizer. Urea is the most commonly used $\mathrm{N}$ fertilizer in Bangladesh, but its efficiency is very low. Wetland soil promotes $\mathrm{N}$ losses through ammonia volatilization, denitrification, leaching and surface runoff when it is applied as prilled form in the soil surface. Urea super granules (USG) is a fertilizer that can be applied in the rice root zone at $8-10 \mathrm{~cm}$ depth of soil which can save $30 \% \mathrm{~N}$ compared to prilled urea, increases absorption rate, improves soil health and ultimately increases rice yield (Savant et al., 1991). Among the various factors responsible for increasing yield quality, fertilizer management is of paramount importance (Novoa and Loomis, 1981). Use of fertilizer and manures is an essential component of modern farming with about 50\% of the world crop production (Prodhan, 2002). Selection of potential variety, planting in appropriate method and application of optimum amount of nutrient elements, can play important role to increase growth and yield of Boro rice. Based on the above information, the experiment was undertaken to study the effect of integrated nutrient management in Boro rice (cv. BRRI dhan29) cultivation. 


\section{MATERIALS AND METHODS}

The experiment was carried out in the farmer's field of village Boira under Kotoali Thana, District-Mymensingh in Boro season (Jannuary to May 2013). The experimental site belongs to the Sonatala series of Old Brahmaputra Floodplain Agroecological Zone (AEZ-9) having non-calcareous dark grey floodplain soils. The soil was silt loam having $\mathrm{pH}$ 6.5. Soil contained $1.67 \%$ organic matter, $0.10 \%$ total $\mathrm{N}, 26.0 \mathrm{ppm}$ available $\mathrm{P}, 0.14$ (me \%) exchangeable $\mathrm{K}$ and $13.9 \mathrm{ppm}$ available $\mathrm{S}$. The experiment consisted of the following treatments- control (no manure and no fertilizer) $\left(\mathrm{T}_{1}\right)$, recommended dose of prilled urea $+\operatorname{PKSZn}\left(\mathrm{T}_{2}\right), 50 \%$ of recommended dose of prilled urea and PKSZn + cowdung $5 \mathrm{t} \mathrm{ha}^{-1}\left(\mathrm{~T}_{3}\right), 50 \%$ of recommended dose of prilled urea and PKSZn + poultry manure $2.5 \mathrm{t} \mathrm{ha}^{-1}\left(\mathrm{~T}_{4}\right), 50 \%$ of recommended dose of prilled urea and PKSZn + cowdung $10 \mathrm{tha}^{-1}\left(\mathrm{~T}_{5}\right), 50 \%$ of recommended dose of prilled urea and PKSZn + poultry manure $5 \mathrm{t} \mathrm{ha}^{-1}\left(\mathrm{~T}_{6}\right)$, cowdung $10 \mathrm{t} \mathrm{ha}^{-1}\left(\mathrm{~T}_{7}\right)$, poultry manure $5 \mathrm{t} \mathrm{ha}^{-1}\left(\mathrm{~T}_{8}\right)$, full dose of USG $(2.7 \mathrm{~g})+$ recommended dose of PKSZn $\left(\mathrm{T}_{9}\right)$, full dose of USG $(2.7 \mathrm{~g})$ + cowdung $10 \mathrm{t} \mathrm{ha}^{-1}$ $\left(\mathrm{T}_{10}\right)$, full dose of USG $(2.7 \mathrm{~g})+$ poultry manure $5 \mathrm{t} \mathrm{ha}^{-1}\left(\mathrm{~T}_{11}\right)$, full dose of USG $(2.7 \mathrm{~g})+$ cowdung $5 \mathrm{t} \mathrm{ha}^{-1}\left(\mathrm{~T}_{12}\right)$, full dose of USG $(2.7 \mathrm{~g})+$ poultry manure $2.5 \mathrm{tha}^{-1}$ $\left(\mathrm{T}_{13}\right)$, USG $(1.8 \mathrm{~g})+$ poultry manure $5 \mathrm{t} \mathrm{ha}^{-1}\left(\mathrm{~T}_{14}\right)$, USG $(1.8 \mathrm{~g})+$ poultry manure $2.5 \mathrm{t}$ $\mathrm{ha}^{-1}\left(\mathrm{~T}_{15}\right)$ and farmer's practice (Urea $250 \mathrm{~kg} \mathrm{ha}^{-1}$, TSP $220 \mathrm{~kg} \mathrm{ha}^{-1}$, MoP $130 \mathrm{~kg} \mathrm{ha}^{-1}$, gypsum $\left.130 \mathrm{~kg} \mathrm{ha}^{-1}\right)\left(\mathrm{T}_{16}\right)$. The experiment was laid out in a randomized complete block design with three replications. Each block was divided into 16 unit plots where the treatment combinations were allocated at random. The size of each unit plot was $4.0 \mathrm{~m} \times 2.5 \mathrm{~m}$. The land was first opened with a tractor drawn plough and finally prepared by ploughing and cross ploughing with country plough followed by laddering. Weeds and stubble were removed from the field as much as possible after leveling. The land was finally prepared and the experiment was laid out on 29 January 2013. Cowdung and poultry manure were applied as basal dose (as per treatment) on 30 January before transplanting of rice seedlings. Urea, triple super phosphate, muriate of potash, gypsum and zinc sulphate @ 250,130, 120, 60 and 10 $\mathrm{kg} \mathrm{ha}^{-1}$, respectively were applied where applicable. The whole amounts of triple super phosphate, muriate of potash, gypsum and zinc sulphate were applied at final land preparation as per experimental specification. Urea was applied in 3 equal splits at 15,30 , and 45 days after transplanting (DAT). As per experimental specification urea super granules (USG) were placed manually (depth 6-8 $\mathrm{cm}$ ) at the centre of four hills of two adjacent rows i.e. once at 10 days after transplanting (DAT) in every alternate row. Thirty seven-day old seedlings were uprooted carefully from the nursery and transplanted on the experimental plots on 01 February 2013 maintaining $25 \mathrm{~cm} \times 15 \mathrm{~cm}$ spacing between the rows and hills, respectively. Weeding was done at 25 and 40 DAT. The crop was irrigated as and when necessary. There was rice stem borer infestation at active tillering stage and it was controlled by Regent $(\mathrm{G})$ applied @ $12.50 \mathrm{~kg} \mathrm{ha}^{-1}$. On the other hand, at milk stage of rice, it was attacked by leaf roller and the insect was successfully controlled by applying Malathion @ $1 \mathrm{ml}$ 
per liter of water. The crops were harvested at full maturity. Maturity of crops was determined when $90 \%$ of the grains became golden yellow in color. The crop was harvested on 29 May 2013. Then the harvested crop of each plot was bundled separately, properly tagged and brought to threshing floor. The crop was then threshed and the fresh weights of grain and straw were recorded plot-wise. The grains were cleaned and finally the weight was adjusted to $14 \%$ moisture content. The straw was sun dried and the yields of grain and straw plot $^{-1}$ were recorded and converted to $\mathrm{t} \mathrm{ha}^{-1}$. Harvest index was calculated with the following formula:

Harvest index $(\%)=\frac{\text { Grain yield }}{\text { Biological yield }} \times 100$.

The collected data were analyzed by using "Analysis of Variance" technique and the differences among treatment means were adjudged by the Duncan's Multiple Range Test (Gomez and Gomez, 1984).

\section{RESULTS AND DISCUSSION}

Crop characters, yield contributing characters and yield of Boro rice were studied as affected by integrated nutrient management. The maximum plant height $\left(93.33 \mathrm{~cm}\right.$ ) was found in $\mathrm{T}_{2}$ treatment (recommended dose of prilled urea and PKSZn) followed by $\mathrm{T}_{8}$ (poultry manure $5 \mathrm{t} \mathrm{ha}^{-1}$ ) and $\mathrm{T}_{9}$ (full dose of USG $(2.7 \mathrm{~g})+$ recommended dose of PKSZn ), while the lowest plant height $(77.60 \mathrm{~cm})$ was found in $\mathrm{T}_{3}$ treatment $(50 \%$ of recommended dose of prilled urea and PKSZn + cowdung $5 \mathrm{t}$ $\left.\mathrm{ha}^{-1}\right)$ which was statistically identical to $\mathrm{T}_{4}(50 \%$ of recommended dose of prilled urea and PKSZn + poultry manure $\left.2.5 \mathrm{tha}^{-1}\right)$ and $\mathrm{T}_{6}(50 \%$ of recommended dose of prilled urea and PKSZn + poultry manure $5 \mathrm{t} \mathrm{ha}^{-1}$ ) (Figure 1). Haga and Dayag (1989) also reported similar results. The highest number of total tillers hill ${ }^{-1}(16.85)$ was obtained with $\mathrm{T}_{11}$ treatment $\left(2.7 \mathrm{~g}\right.$ USG + poultry manure $\left.5 \mathrm{t} \mathrm{ha}^{-1}\right)$ which was statistically identical to $\mathrm{T}_{9}$ (full dose of USG $(2.7 \mathrm{~g}$ ) + recommended dose of PKSZn ) and $\mathrm{T}_{13}$ (full dose of USG $(2.7 \mathrm{~g})+$ poultry manure $2.5 \mathrm{t} \mathrm{ha}^{-1}$ ) that was the lowest (8.13) with $\mathrm{T}_{4}$ treatment $(50 \%$ of recommended dose of prilled urea and PKSZn + poultry manure $2.5 \mathrm{t} \mathrm{ha}^{-1}$ ) (Table 1 ). Total tillers hill ${ }^{-1}$ was positively correlated with level of nitrogen application as reported by BRRI (1991) and Kamal et al. (1999). The highest number of effective tillers hill ${ }^{-1}(15.90)$ was obtained in $\mathrm{T}_{11}$ treatment (USG $2.7 \mathrm{~g}+$ poultry manure $5 \mathrm{t} \mathrm{ha}^{-1}$ ) followed by $\mathrm{T}_{13}$ (full dose of USG $(2.7 \mathrm{~g})+$ poultry manure $2.5 \mathrm{t} \mathrm{ha}^{-1}$ ) and $\mathrm{T}_{9}$ (full dose of USG $(2.7 \mathrm{~g})+$ recommended dose of PKSZn) and that was the lowest (7.23) in $\mathrm{T}_{4}$ treatment (50\% of recommended dose of prilled urea and PKSZn + poultry manure $2.5 \mathrm{t} \mathrm{ha}^{-1}$ ) (Figure 2). Combined application of inorganic fertilizer and manure increased effective tillers hill ${ }^{-1}$ was reported by Islam et al. (2015). Ahmed and Rahman (1991) differing in view that organic and inorganic fertilizers increased tiller number hill ${ }^{-1}$. Adequacy of nitrogen as USG probably favoured the cellular activities during panicle development, which led to increased number of effective tillers hill ${ }^{-1}$. The highest number of non-effective 
tillers hill ${ }^{-1}$ (1.41) was obtained in $\mathrm{T}_{9}$ treatment (USG 2.7g + recommended dose of PKSZn) which was statistically identical to $\mathrm{T}_{7}$ (cowdung $10 \mathrm{t} \mathrm{ha}^{-1}$ ) and $\mathrm{T}_{12}$ (full dose of USG $(2.7 \mathrm{~g})+$ cowdung $5 \mathrm{t} \mathrm{ha}^{-1}$ ) and the lowest $(0.67)$ in $\mathrm{T}_{16}$ treatment (farmer's practice: Urea-TSP-MoP-Gypsum @ 250-220-130-130 kg ha ${ }^{-1}$ ) (Table 1). The highest length of panicle $(26.77 \mathrm{~cm})$ was obtained with $\mathrm{T}_{2}$ treatment (recommended dose of prilled urea and PKSZn) followed by $\mathrm{T}_{16}$ treatment (farmer's practice: UreaTSP-MoP-Gypsum @ 250-220-130-130 kg ha ${ }^{-1}$ ) and the lowest one was recorded in $\mathrm{T}_{1}$ (control) treatment $(23.20 \mathrm{~cm})$ (Table 1). Nassai and Vargas (1982) found shorter panicle length in lower doses of fertilizer. The highest panicle weight $(4.31 \mathrm{~g})$ was found in $\mathrm{T}_{14}$ treatment (USG $1.8 \mathrm{~g}+$ poultry manure $5 \mathrm{t} \mathrm{ha}^{-1}$ ) and the lowest panicle weight $\left(1.40 \mathrm{~g}\right.$ ) was found in $\mathrm{T}_{2}$ treatment (recommended dose of prilled urea and PKSZn). The number of grains panicle ${ }^{-1}$ was maximum (205.30) in $\mathrm{T}_{9}$ treatment (full dose of USG (2.7g) and recommended dose of PKSZn) which was as good as $\mathrm{T}_{13}$ (full dose of USG $(2.7 \mathrm{~g})+$ poultry manure $2.5 \mathrm{tha}^{-1}$ ) and minimum (122.0) in $\mathrm{T}_{5}$ treatment $\left(50 \%\right.$ of recommended dose of prilled urea and PKSZn + cowdung $10 \mathrm{tha}^{-}$ $\left.{ }^{1}\right)$. Nitrogen helped in proper filling of seeds, which resulted higher produced plump seeds and thus the number of grains panicle ${ }^{-1}$. Islam et al. (2014) reported that the number of grains panicle ${ }^{-1}$ increased significantly with increments in level of nitrogen. Similar observation was also reported elsewhere (Jisan et al., 2014; Salahuddin et al., 2009; ). Combined application of manures and fertilizers increased number of grains panicle ${ }^{-1}$ (Malika, 2011; Rahman et al., 2007 and Parvez et al., 2008). The number of sterile spikelets panicle ${ }^{-1}$ was maximum (27.95) in $T_{2}$ treatment (recommended dose of prilled urea and PKSZn) and minimum (9.04) in $\mathrm{T}_{9}$ treatment (full dose of USG (2.7g) and recommended dose of PKSZn). The highest 1000-grain weight $(22.40 \mathrm{~g})$ was found at $\mathrm{T}_{10}$ treatment (Full dose of USG $(2.7 \mathrm{~g})+$ cowdung $10 \mathrm{t}$ $\left.\mathrm{ha}^{-1}\right)$ which was statistically identical to $\mathrm{T}_{15}\left(1.8 \mathrm{~g}\right.$ USG + poultry manure $\left.2.5 \mathrm{t} \mathrm{ha}^{-1}\right)$, $\mathrm{T}_{14}\left(1.8 \mathrm{~g}\right.$ USG + poultry manure $5 \mathrm{t} \mathrm{ha}^{-1}$ ), $\mathrm{T}_{13}$ (full dose, $2.7 \mathrm{~g} \mathrm{USG}+$ poultry manure $2.5 \mathrm{t} \mathrm{ha}^{-1}$ ) and $\mathrm{T}_{9}$ treatment (USG 2.7g and recommended dose of PKSZn), while the lowest one (17.41 g) was found in $\mathrm{T}_{1}$ treatment (control) (Table 1). The weight of 1000-grain increased significantly with increasing nitrogen levels, which was also reported by Baligar and Ganin (2001). Application of manure and fertilizers increased 1000-grain weight, also reported by Rahman et al. (2007) and Parvez et al. (2008). The highest grain yield $\left(7.19 \mathrm{t} \mathrm{ha}^{-1}\right)$ was recorded from $\mathrm{T}_{10}$ treatment $(2.7 \mathrm{~g}$ USG + cowdung $10 \mathrm{t} \mathrm{ha}^{-1}$ ) followed by $\mathrm{T}_{2}$ (recommended dose of prilled urea and PKSZn) and the lowest grain yield $\left(4.43 \mathrm{t} \mathrm{ha}^{-1}\right)$ was recorded in $\mathrm{T}_{7}$ treatment (cowdung $10 \mathrm{t} \mathrm{ha}^{-1}$ ) (Figure 3). The highest grain yield was favored by crop characters like effective tillers hill ${ }^{-1}$ and number of grains panicle ${ }^{-1}$. This result is in conformity with the findings of Sarkar et al. (2014) and Singh and Pillar (1996). The highest straw yield $\left(8.09 \mathrm{t} \mathrm{ha}^{-1}\right.$ ) was found inT $_{2}$ treatment (recommended dose of prilled urea and PKSZn) which was statistically identical to $\mathrm{T}_{10}$ (full dose of USG $(2.7 \mathrm{~g})+$ cowdung $\left.10 \mathrm{t} \mathrm{ha}^{-1}\right)$ and $\mathrm{T}_{15}\left(1.8 \mathrm{~g} \mathrm{USG}+\right.$ poultry manure $\left.2.5 \mathrm{t} \mathrm{ha}^{-1}\right)($ Table 1$)$ while the lowest straw yield $\left(5.21 \mathrm{t} \mathrm{ha}^{-1}\right)$ was recorded in $\mathrm{T}_{7}$ treatment (cowdung $10 \mathrm{t}$ 
$\mathrm{ha}^{-1}$ ). The highest straw yield was found in $\mathrm{T}_{2}$ treatment (recommended dose of prilled urea and PKSZn), which occurred due to the tallest plants and more number of tillers hill ${ }^{-1}$. However, $\mathrm{T}_{10}$ treatment (USG $2.7 \mathrm{~g}+$ cowdung $10 \mathrm{t} \mathrm{ha}^{-1}$ ) and $\mathrm{T}_{15}$ treatment (USG $1.8 \mathrm{~g}+$ poultry manure $2.5 \mathrm{t} \mathrm{ha}^{-1}$ ) were comparable to $\mathrm{T}_{2}$ treatment (recommended dose of prilled urea and PKSZn) in respect of straw yield. The highest biological yield (15.27 $\mathrm{t} \mathrm{ha}^{-1}$ ) was obtained from $\mathrm{T}_{2}$ treatment (recommended dose of prilled urea and PKSZn) and the lowest biological yield $\left(9.64 \mathrm{t} \mathrm{ha}^{-1}\right)$ was obtained $\mathrm{inT}_{7}$ treatment (cowdung $10 \mathrm{t} \mathrm{ha}^{-1}$ ) (Table 1). The highest harvest index $(47.31 \%)$ was recorded in $\mathrm{T}_{11}$ treatment $\left(2.7 \mathrm{~g}\right.$ USG + poultry manure $\left.5 \mathrm{t} \mathrm{ha}^{-1}\right)$ and the lowest harvest index $(45.49 \%)$ was found in $\mathrm{T}_{4}$ treatment $(50 \%$ of recommended dose of prilled urea and PKSZn + poultry manure $2.5 \mathrm{t} \mathrm{ha}^{-1}$ ) (Table 1$)$.

\section{CONCLUSION}

From the study it can be concluded that integrated nutrient can increase grain yield of Boro rice. Full dose of USG (2.7g) with cowdung $\left(10 \mathrm{t} \mathrm{ha}^{-1}\right)$ appears as the promising combination for Boro rice cultivation.

\section{ACKNOWLEDGEMENTS}

The authors thankfully acknowledge the financial assistance of the British Council to conduct the research project.

\section{REFERENCES}

Ahmed, F. and Rahman, M. 1991. Yield response of rice to fertilizers with and without manure. Proc. $11^{\text {th }}$ Ann. Bangladesh Sci. Conf. Sec. 1.Bangladesh Assoc. Advan. Sci. Dhaka, Bangladesh: 68

Baligar, A. S. and Ganin, B. A. 2001. Response of rice genotypes to nitrogen level under transplanted condition in Brazil. Newsletter, 9 (5): 29-31

BBS,Bangladesh Bureau of Statistics. 2012. Statistical Yearbook of Bangladesh. Bangladesh Bur. Stat., Stat. Div., Minis. Plann. Govt. People's Repub. Bangladesh, Dhaka. pp. 123-127

Bhatia, K. S. and Shukla, K. K. 1982. Effect of continuous application of fertilizers and manures on some physical properties of (eroded) alluvial soil. Journal of the Indian Society of Soil Science, 30(1): 33-36.

BRRI,Bangladesh Rice Research Institute. 1991. Annual Report for 1990. Bangladesh Rice Res. Inst., Joydebpur, Gazipur. pp. 5-13

Gomez, K. A, and Gomez, A. A. 1984. Statistical Procedures for Agricultural Research. Intl. Rice Res. Inst., John Wiley and Sons. New York, Chickester, Brisbane, Toronto, Singapore, p. 680

Haga, L. G. and Dayag, A. M. 1989. Study on the use of four locally processed organic fertilizer in combination with chemical fertilizer on low land rice. Philippines: 6-7: 96 
Islam, M. S., Paul, S. K. and Sarkar, M. A. R. 2014. Varietal performance of modern transplant Aman rice subjected to level of nitrogen application. Journal of the Bangladesh Agricultural University, 12 (1): 55-60

Islam, S. M. M., Paul, S. K. and Sarkar, M. A. R. 2015. Effect of weeding regime and integrated nutrient management on yield contributing characters and yield of BRRI dhan49. Journal of Crop and Weed, 11: 193-197

Jisan, M. T., Paul, S. K. and Salim M. 2014. Yield performance of some transplant aman ric varieties as influenced by different levels of nitrogen. Journal of the BangladeshAgricultural University, 12 (2): 321-324

Kamal, A. M. A., Islam, M. R. and Chowdhury, B. L. D. 1999. Growth performance protein content and nutrient uptake by modern varieties of rice under irrigated condition in Bangladesh. Thai Journal of Agricultural Science, 32(1): 105-110

Lal, S. and B. S. Mathur. 1988. Effect of long term manuring, fertilization and liming on crop yield and some physical properties of acid soil. Journal of the Indian Society of Soil Science, 36:113-119

Malika, M. 2011. Combined use of manures and fertilizers for maximizing the growth and yield of BINA dhan7. M. S. thesis, Department of Soil Science, Bangladesh Agricultural University, Mymensingh

Nambiar, K. K. M. and Abrol, I. P. 1989. Long term fertilizer experiments in India an overview. Fertilizer News, 34(4): 11-20

Nassai, K. K. M. and Vargas, I. P. 1982. Long term fertilizer experiments in India an overview. Fertilizer News, 34(4): 11-20

Novoa, R. and Loomis, R. S. 1981. Nitrogen and plant production. Plant and Soil. 58: 177 204. NPK combinations on the yield contributing characters of rice. Bangladesh Journal of Agricultural Sciences, 15(1): 105-110

Parvez, M. S., Islam, M. R., Begum, M. S., Rahman, M. S., and Abedin Miah, M. J. 2008. Integrated use of manure and fertilizers for maximizing the of BRRI dhan30. Journal of Bangladesh Society of Agricultural Science and Technology, 5 (1 \& 2): 257-260

Prodhan, S. B. 2002. "Status of fertilizer use in developing countries of Asia and the pacific region”: Proc. Regi. FADINAP seminar, Chiang Mai, Thailand. pp. 37-47

Rabindra, B., Narayanawamy, G.V., Janardhan, N.A. and Shivanagappa. 1985. Long range effect of manure and fertilizers on soil physical properties and yield of sugarcane. Journal of the Indian Society of Soil Science, 33:704-706

Rahman, M. S., Islam, M. R., Naser, H. M., Hoque, M. M and Hossain, A. (2007). Effects of combined use of manures and fertilizers on the yield and nutrient uptake by BRRI dhan30. Journal of Bangladesh Society of Agricultural Science and Technology, 4 (3 \& 4): $37-40$

Sarkar, S. K., Sarkar, M. A. R., Islam, N. and Paul, S. K. 2014. Yield and quality of aromatic fine rice as affected by variety and nutrient management. Journal of the Bangladesh Agricultural University, 12 (2): 279-284 
Savant, A. C., Thorat, S. T., Khadse, R. R. and Bhosale, R. J. 1991. Response of early rice varieties to nitrogen levels and spacing in coastal Maharashtra. Journal of Maharashtra Agricultural University, 11(2):182-184

Salahuddin, K. M., Chowdhury, S. H., Munira, S., Islam, M. M. and Parvin, S. 2009. Response of nitrogen and plant spacing transplanted aman rice. Bangladesh Journal of Agricultural Research, 34(2): 279- 285

Singh, A. S. and Pillar, N. 1996. Nitrogen fertilizer in transplant rice. International Rice Research Newsleller, 8(5): p. 27

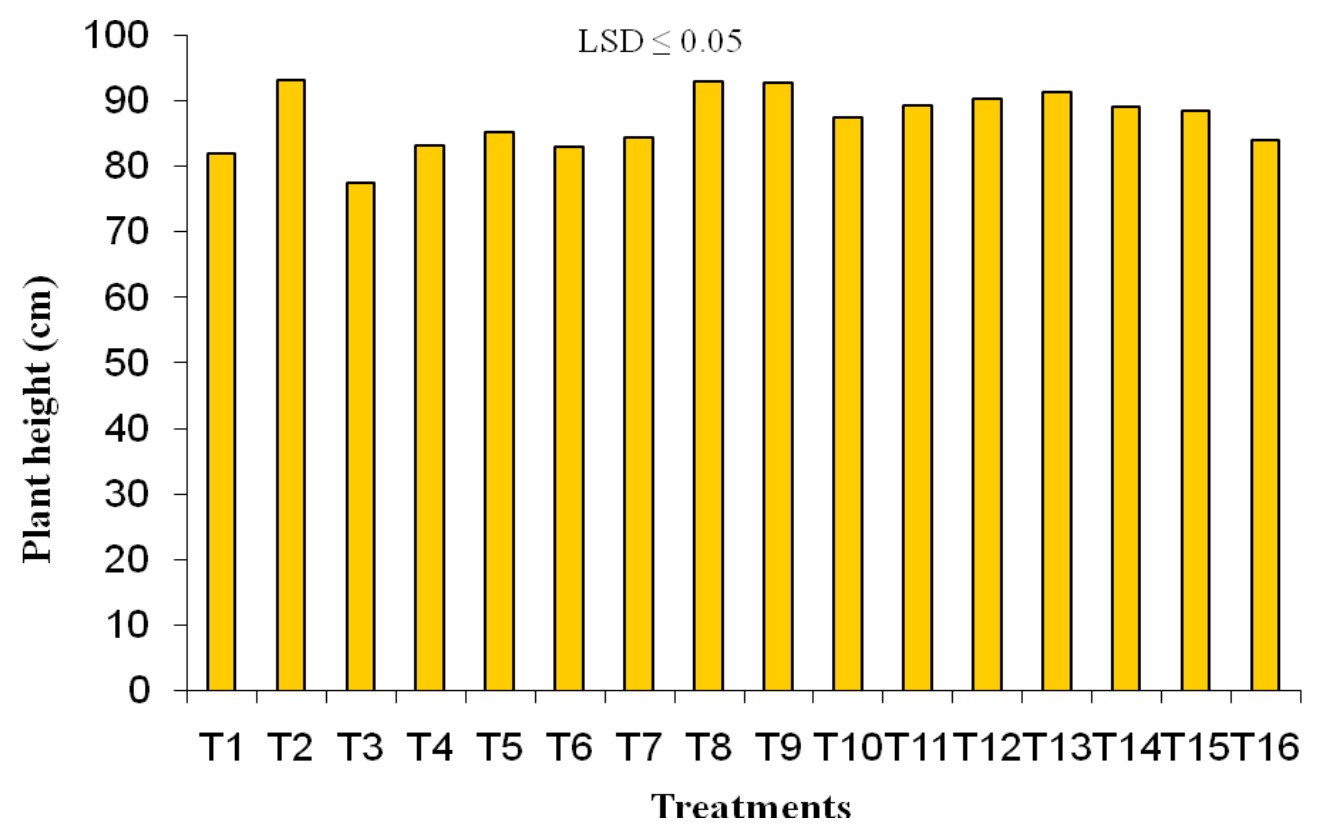

Figure 1. Effect of integrated nutrient management on plant height 


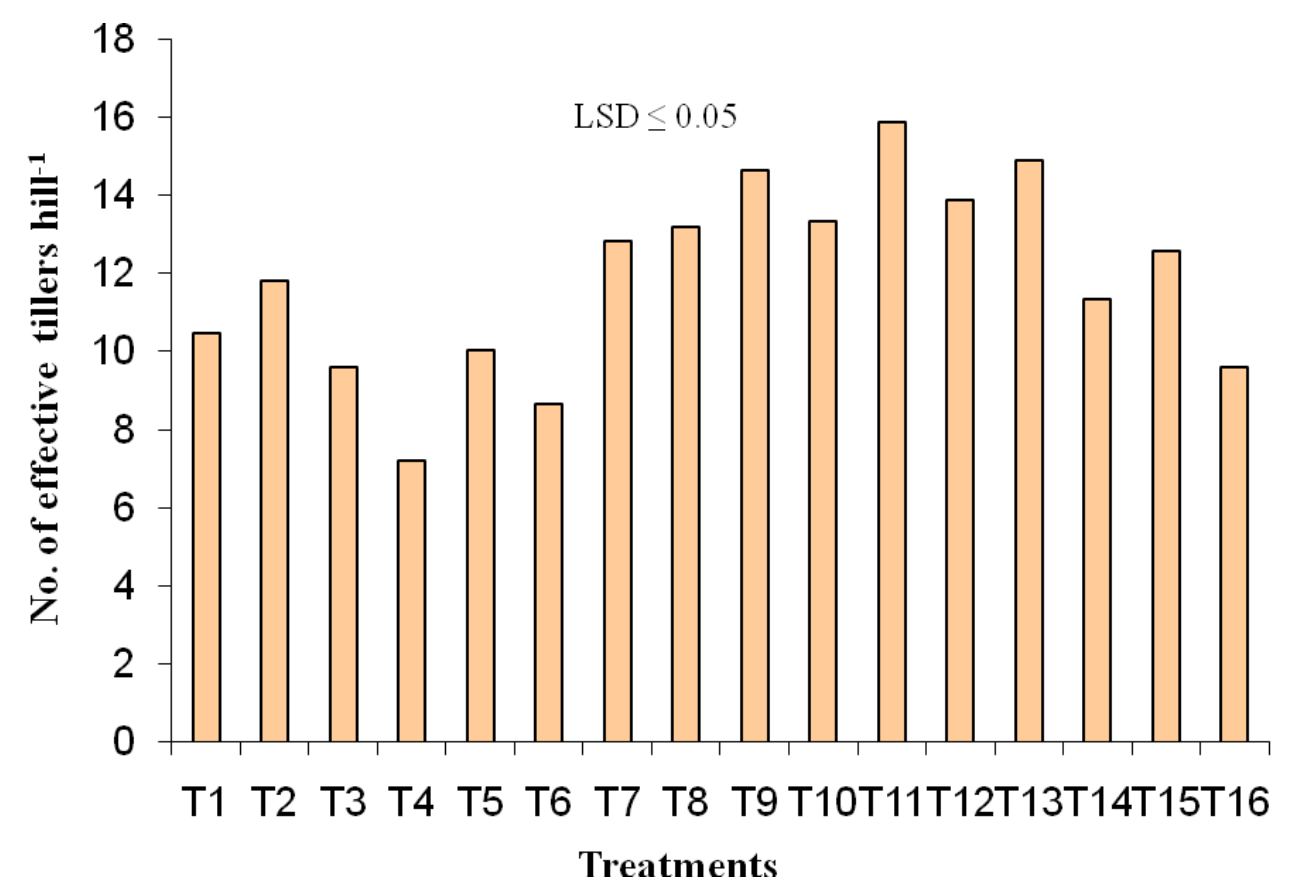

Figure 2. Effect of integrated nutrient management on no. of effective tillers hill ${ }^{-1}$

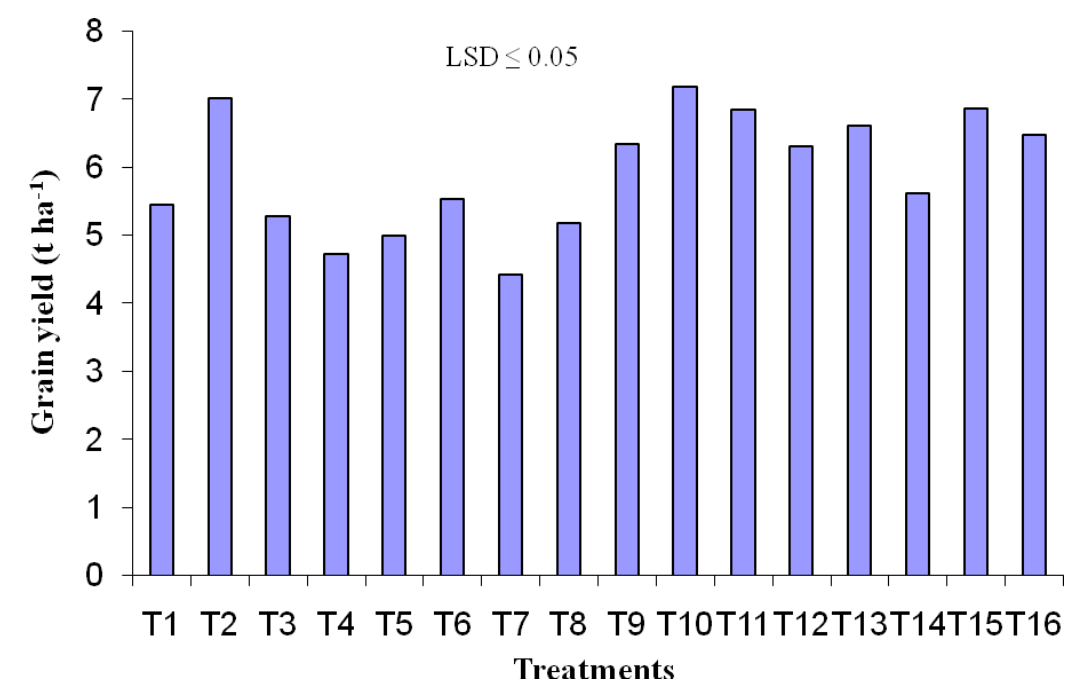

Figure 3. Effect of integrated nutrient management on grain yield 
SAARC J. Agri., 13(2): 131-140 (2015)

Table 1. Effect of integrated nutrient management on crop characters, yield components and yield of Boro rice

\begin{tabular}{|c|c|c|c|c|c|c|c|c|c|c|}
\hline Treatments & $\begin{array}{l}\text { No. of total } \\
\text { tillers hill }\end{array}$ & $\begin{array}{l}\text { No. of non- } \\
\text { effective } \\
\text { tillers hill }^{-1} \\
\end{array}$ & $\begin{array}{l}\text { Panicle } \\
\text { length } \\
(\mathrm{cm})\end{array}$ & $\begin{array}{c}\text { Panicle } \\
\text { weight }(\mathrm{g})\end{array}$ & $\begin{array}{c}\text { Grains } \\
\text { panicle }^{-1}\end{array}$ & $\begin{array}{c}\text { Sterile } \\
\text { spikelets } \\
\text { panicle }^{-1}\end{array}$ & \begin{tabular}{|c|} 
Weight of \\
1000 grains \\
$(\mathrm{g})$
\end{tabular} & $\begin{array}{c}\text { Straw yield } \\
\left(\mathrm{t} \mathrm{ha}^{-1}\right)\end{array}$ & $\begin{array}{c}\text { Biological } \\
\text { yield } \\
\left(\mathrm{t} \mathrm{ha}^{-1}\right) \\
\end{array}$ & $\begin{array}{l}\text { Harvest } \\
\text { index }(\%)\end{array}$ \\
\hline $\mathrm{T}_{1}$ & $11.46 \mathrm{fg}$ & $0.983 \mathrm{de}$ & $23.20 \mathrm{~d}$ & $1.770 \mathrm{f}$ & $138.2 \mathrm{fg}$ & $17.84 \mathrm{c}$ & $17.41 \mathrm{~g}$ & 6.34def & $11.79 \mathrm{fg}$ & $46.23 \mathrm{cde}$ \\
\hline $\mathrm{T}_{2}$ & $12.80 \mathrm{e}$ & $0.963 \mathrm{de}$ & $26.77 \mathrm{a}$ & $1.40 \mathrm{~g}$ & $196.6 \mathrm{ab}$ & $27.95 \mathrm{a}$ & 19.60cde & $8.09 \mathrm{a}$ & $15.12 \mathrm{ab}$ & 46.49bcd \\
\hline $\mathrm{T}_{3}$ & $10.84 \mathrm{gh}$ & $1.233 \mathrm{abc}$ & $23.38 \mathrm{~cd}$ & $2.40 \mathrm{e}$ & $149.4 \mathrm{f}$ & $27.61 \mathrm{~b}$ & 18.40 efg & $6.27 \mathrm{def}$ & $11.55 \mathrm{fgh}$ & 45.71def \\
\hline $\mathrm{T}_{4}$ & $8.140 \mathrm{j}$ & $0.9067 \mathrm{e}$ & $26.38 \mathrm{a}$ & $3.57 \mathrm{~b}$ & $132.1 \mathrm{gh}$ & $15.00 \mathrm{~d}$ & $17.90 \mathrm{fg}$ & $5.68 \mathrm{~g}$ & $10.41 \mathrm{i}$ & $45.49 \mathrm{f}$ \\
\hline $\mathrm{T}_{6}$ & $9.680 \mathrm{i}$ & $1.00 \mathrm{de}$ & $25.33 \mathrm{abc}$ & $2.747 \mathrm{~d}$ & $168.3 \mathrm{e}$ & 12.67 ef & 19.10 def & $6.43 \mathrm{de}$ & $11.97 \mathrm{fg}$ & $46.28 \mathrm{cde}$ \\
\hline $\mathrm{T}_{7}$ & $14.21 \mathrm{~d}$ & $1.357 \mathrm{ab}$ & $25.95 \mathrm{ab}$ & $1.70 \mathrm{fg}$ & $124.9 \mathrm{~h}$ & $16.40 \mathrm{~cd}$ & $18.31 \mathrm{efg}$ & $5.21 \mathrm{~h}$ & $9.64 \mathrm{j}$ & $45.95 \mathrm{de}$ \\
\hline $\mathrm{T}_{8}$ & $14.18 \mathrm{~d}$ & $0.977 \mathrm{de}$ & $25.83 b$ & $2.00 \mathrm{f}$ & $138.2 \mathrm{fg}$ & 12.47 ef & 18.50efg & $6.11 \mathrm{ef}$ & $11.30 \mathrm{gh}$ & 45.93de \\
\hline $\mathrm{T}_{9}$ & 16.06ab & $1.410 \mathrm{a}$ & $25.62 \mathrm{ab}$ & $2.68 \mathrm{de}$ & $205.3 \mathrm{a}$ & $9.04 \mathrm{~h}$ & $21.44 \mathrm{ab}$ & $7.22 \mathrm{c}$ & $13.56 \mathrm{e}$ & $46.76 \mathrm{bc}$ \\
\hline $\mathrm{T}_{10}$ & $14.37 \mathrm{~cd}$ & $1.00 \mathrm{de}$ & 24.90abcd & $3.52 \mathrm{~b}$ & $180.9 \mathrm{cde}$ & $12.98 \mathrm{e}$ & $22.40 \mathrm{a}$ & $8.08 \mathrm{a}$ & $15.27 \mathrm{a}$ & $47.09 \mathrm{ab}$ \\
\hline $\mathrm{T}_{14}$ & $12.25 \mathrm{ef}$ & $0.890 \mathrm{e}$ & 24.93abcd & $4.31 \mathrm{a}$ & $196.3 \mathrm{ab}$ & $16.05 \mathrm{~d}$ & $21.41 \mathrm{ab}$ & $6.60 \mathrm{~d}$ & $12.22 \mathrm{f}$ & 45.99cde \\
\hline $\mathrm{T}_{15}$ & $13.78 \mathrm{~d}$ & $1.183 \mathrm{bcd}$ & $26.51 \mathrm{a}$ & $3.297 \mathrm{bc}$ & $178.9 \mathrm{de}$ & $11.01 \mathrm{fg}$ & $22.12 \mathrm{a}$ & $7.81 \mathrm{ab}$ & $14.68 \mathrm{abc}$ & $46.8 \mathrm{bc}$ \\
\hline $\mathrm{T}_{16}$ & 10.28hi & \begin{tabular}{|l|}
$0.670 \mathrm{f}$ \\
\end{tabular} & 25.48 abc & $\begin{array}{|ll|}3.550 & \mathrm{~b} \\
\end{array}$ & $191.5 \mathrm{bcd}$ & $12.73 \mathrm{e}$ & $21.10 \mathrm{abc}$ & $7.44 \mathrm{bc}$ & $13.91 \mathrm{de}$ & $46.55 \mathrm{~cd}$ \\
\hline $\mathrm{LSD}_{0.05}$ & 0.925 & \begin{tabular}{|l|}
0.204 \\
\end{tabular} & 1.82 & \begin{tabular}{|l|}
0.312 \\
\end{tabular} & 12.02 & 1.55 & 1.45 & 0.411 & 0.76 & - \\
\hline Level of sign. & $* *$ & $* *$ & $* *$ & $* *$ & $* *$ & $* *$ & $* *$ & $* *$ & $* *$ & $* *$ \\
\hline $\mathrm{SE}( \pm)$ & 0.32 & 0.071 & 0.632 & 0.107 & 4.16 & 0.536 & 0.505 & 0.142 & 0.263 & 0.434 \\
\hline $\mathrm{CV}(\%)$ & 4.28 & 11.59 & 4.35 & 6.44 & 4.26 & 5.88 & 4.42 & 3.59 & 3.56 & 1.62 \\
\hline
\end{tabular}

In a column, figures with same letter or without letter do not differ significantly whereas figures with dissimilar letters differ significantly as per DMRT

$* *=$ Significant at $1 \%$ level of probability. 